\title{
Differential effect on different immune subsets of neoadjuvant chemotherapy in patients with TNBC
}

\begin{abstract}
Chiara Massa, ${ }^{1}$ Thomas Karn (D) , ${ }^{2}$ Carsten Denkert, ${ }^{3}$ Andreas Schneeweiss, ${ }^{4}$ Claus Hanusch, ${ }^{5}$ Jens-Uwe Blohmer, ${ }^{6}$ Dirk-Michael Zahm, ${ }^{7}$ Christian Jackisch, ${ }^{8}$ Marion van Mackelenbergh, ${ }^{9}$ Jörg Thomalla, ${ }^{10}$ Frederik Marme, ${ }^{11}$ Jens Huober, ${ }^{12}$ Volkmar Müller, ${ }^{13}$ Christian Schem, ${ }^{14}$ Anja Mueller, ${ }^{1}$ Elmar Stickeler, ${ }^{15}$ Katharina Biehl, ${ }^{1}$ Peter A Fasching, ${ }^{16}$ Michael Untch, ${ }^{17}$ Sibylle Loibl, ${ }^{18}$ Karsten Weber, ${ }^{18}$ Barbara Seliger (i) ${ }^{1}$
\end{abstract}

To cite: Massa C, Karn T, Denkert C, et al. Differential effect on different immune subsets of neoadjuvant chemotherapy in patients with TNBC. Journal for ImmunoTherapy of Cancer 2020;8:e001261. doi:10.1136/ jitc-2020-001261

- Additional material is published online only. To view, please visit the journal online (http://dx.doi.org/10.1136/jitc2020-001261).

This article was partially presented at the American Society of Clinical Oncology, Annual Meeting May 31-June 4, 2019, Chicago, Illinois, USA.

Accepted 09 October 2020

\section{ABSTRACT}

Background Triple-negative breast cancer (TNBC) is the most aggressive form of breast cancer (BC). Due to the absence of targets such as HER2 or hormone receptors, early TNBC is treated with surgery and chemotherapy. Since TNBC is also considered the most immunogenic type of $\mathrm{BC}$ with tumor infiltrating lymphocytes that are predictive for chemotherapy response and prognostic for patients' survival, many different immunotherapeutic strategies are currently explored in clinical trials for the treatment of this disease. In order to efficiently combine chemotherapy with immunotherapy, it is important to evaluate the effect of chemotherapy on immune cells in vivo.

Methods Peripheral blood was taken from 56 patients with TNBC undergoing neoadjuvant chemotherapy with nanoparticle albumin-bound paclitaxel (Nab-Pac) followed by epirubicin and cyclophosphamide (EC) at three different time points. Multicolor flow cytometry was used to characterize the immune cell composition and functional properties along neoadjuvant chemotherapy.

Results Whereas the first phase of the neoadjuvant chemotherapy did not significantly alter the patients' immune cell composition, after the second phase of chemotherapeutic administration most B cells ( $>90 \%)$ were lost and the frequency of natural killer (NK) cells and $\mathrm{CD}^{+} \mathrm{T}$ Iymphocytes decreased approximately to $50 \%$. In contrast, the frequency of $\mathrm{CD}^{+} \mathrm{T}$ cells were less affected. Conclusions Despite late consequences of Nab-Pac cannot be ruled out, these data suggest that different chemotherapeutics might have distinct effects on the immune cell repertoire and that different immune cell populations exhibit a specific susceptibility to these chemotherapies with B and NK cells being more affected than $\mathrm{T}$ cells. This might also have an impact on the combination of chemotherapies with immunotherapies. Trial registration number NCT02685059.

\section{INTRODUCTION}

Breast cancer (BC) is the most common tumor in women with worldwide almost 2 million new cases per year and >600 000 deaths recorded in 2018 (WHO website).
Among the different subtypes of BC, the triple-negative breast cancer (TNBC) is defined as negative for the expression of the epidermal growth factor receptor 2 , the estrogen and the progesterone receptors and has the worst prognosis. Due to the absence of targetable driver mutations, the standard treatment for TBNC in both early and recurrent metastatic patients is surgery followed by chemotherapy in an adjuvant setting. Recently, chemotherapy has been increasingly used in a preoperative, neoadjuvant setting. ${ }^{1}$

Studies performed in the last decade suggest that TNBC is the most immunogenic BC subtype with a high frequency of tumor infiltrating lymphocytes (TIL), which have a prognostic value for the clinical outcome of patients. ${ }^{2}$ Based on these results, various immunotherapeutic strategies, including immune checkpoint inhibitors (iCPI), are currently applied to TNBC, mainly in combination with chemotherapy. ${ }^{3}{ }^{4}$ For many chemotherapeutic compounds used for TNBC treatment, some dose-dependent positive and/or negative immunomodulatory activities have been reported. ${ }^{5}$ Thus, it is mandatory to evaluate the effect of chemotherapy on the patients' immune system in order to determine the feasibility of such combinatorial approaches as well as to select the best combination strategy regarding the employed immunotherapy approach and its respective timing with chemotherapy. In addition, markers to stratify patients that might benefit from neoadjuvant chemotherapy in combination with immunotherapy are needed.

Therefore, we performed an exploratory immune monitoring on the peripheral 
blood of patients with TNBC undergoing only neoadjuvant chemotherapy, namely the placebo arm of the GeparNuevo study. ${ }^{3}$ In brief, after patients' consent to participate in the study, blood was taken (i) at time of recruitment, (ii) after the first phase of treatment with $125 \mathrm{mg} / \mathrm{m}^{2}$ nanoparticle albumin-bound paclitaxel (Nab-Pac) weekly for 12 weeks and (iii) at surgery, after the second phase treatment with standard doses of epirubicin $\left(90 \mathrm{mg} / \mathrm{m}^{2}\right.$ intravenous) and cyclophosphamide (600 $\mathrm{mg} / \mathrm{m}^{2}$ intravenous) (EC) given every 2 weeks for 4 cycles. Multicolor flow cytometry was used to characterize changes in the immune repertoire of the patients along treatment and data were also evaluated for association with the pathological complete response (pCR) defined as ypT0 ypN0 according to the GeparNuevo protocol. The results demonstrated that during the first phase there were limited effects on the immune cell composition of peripheral blood, whereas a pronounced effect was shown after completing the neoadjuvant chemotherapy with EC when an almost complete loss of B cells and halving of natural killer (NK) cells as well as $\mathrm{CD} 4^{+}$ $\mathrm{T}$ lymphocytes was detected. In contrast, $\mathrm{CD} 8^{+} \mathrm{T}$ cells as well as monocytes and granulocytes were only marginally affected by the different phases of chemotherapy.

\section{PATIENTS DATA AND METHODS Patients' cohort and blood samples}

A total of 56 patients undergoing neoadjuvant chemotherapy and representing the placebo arm of the GeparNuevo trial underwent immune monitoring on blood samples collected at three different time points of the treatment: (i) time point A, at recruitment; (ii) time point B, after 12 weeks of treatment with $125 \mathrm{mg} / \mathrm{m}^{2} \mathrm{Nab}-\mathrm{Pac}$ and (iii) time point $\mathrm{C}$, at surgery, performed after 8 weeks biweekly treatment with $90 \mathrm{mg} / \mathrm{m}^{2}$ epirubicin and 600 $\mathrm{mg} / \mathrm{m}^{2}$ cyclophosphamide (EC) (online supplemental figure 1). Blood samples were collected in recruiting centers using EDTA monovette and then centrally analyzed in the Institute of Medical Immunology at the Martin Luther University in Halle within 24 hours from the blood draw. A summary of patients' characteristics is given in table 1.

\section{Flow cytometric evaluation}

\section{Staining and gating strategies}

Whole blood was used (i) for determination of the absolute cell counts per $\mu \mathrm{L}$ blood of different immune cell subsets and (ii) for further deeper phenotypical analysis of the different immune cell populations. All samples were measured on an LSR Fortessa II (BD Bioscience) flow cytometer that was weekly controlled with the CST beads (BD Bioscience). Data were analyzed using the Diva software (BD Bioscience).

Absolute cell counts determination

To obtain absolute cell counts, the BD Trucount tubes (BD Biosciences) were used in combination with the
Table 1 Patients' characteristics $(n=56)$

\begin{tabular}{|c|c|c|}
\hline Parameter & Category & $\begin{array}{l}\text { No. of } \\
\text { analyzed } \\
\text { patients (\% } \\
\text { of total) }\end{array}$ \\
\hline \multirow[t]{6}{*}{ Age, years } & $<30$ & 2 (3.6\%) \\
\hline & $30-40$ & $8(14.3 \%)$ \\
\hline & $40-50$ & 17 (30.4\%) \\
\hline & $50-60$ & 17 (30.4\%) \\
\hline & $60-70$ & $11(19.6 \%)$ \\
\hline & $>70$ & $1(1.8 \%)$ \\
\hline \multirow[t]{3}{*}{ Grading } & G1 & $0(0.0 \%)$ \\
\hline & G2 & $11(19.6 \%)$ \\
\hline & G3 & $45(80.4 \%)$ \\
\hline \multirow[t]{4}{*}{ Nodal status } & $\mathrm{cNO}$ & $40(71.4 \%)$ \\
\hline & $\mathrm{cN} 1$ & $13(23.2 \%)$ \\
\hline & $\mathrm{cN} 2$ & $1(1.8 \%)$ \\
\hline & $\mathrm{cN3}$ & $2(3.6) \%$ \\
\hline \multirow[t]{4}{*}{ Tumor size } & cT1 & $23(41.1 \%)$ \\
\hline & cT2 & $32(57.1 \%)$ \\
\hline & cT3 & $1(1.8 \%)$ \\
\hline & cT4 & $0(0.0 \%)$ \\
\hline \multirow[t]{3}{*}{ Stromal TILs } & $0 \%-10 \%$ & $20(35.7 \%)$ \\
\hline & $11 \%-59 \%$ & $28(50.0 \%)$ \\
\hline & $\geq 60 \%$ & $8(14.3 \%)$ \\
\hline Parameter & Measure & Value \\
\hline \multirow[t]{2}{*}{ Ki67 } & Mean $\pm S D$ & $50.0 \pm 19.4$ \\
\hline & Min, median, $\max$ & $9-48-92$ \\
\hline \multirow[t]{2}{*}{ Stromal TILs } & Mean \pm SD & $24.4 \pm 21.1$ \\
\hline & Min, median, $\max$ & $0-17-80$ \\
\hline
\end{tabular}

TIL, tumor infiltrating lymphocyte.

6-color TBNK kit (BD Biosciences or Exbio Antibodies) according to the manufacturer's instructions. Briefly, $50 \mu \mathrm{L}$ of blood were incubated at room temperature (RT) for $15 \mathrm{~min}$ with $20 \mu \mathrm{L}$ of the TBNK antibody mixture in the Trucount tubes. The erythrocytes were then lysed by 10 min incubation in the BD FACS lysing solution (BD Bioscience) and the samples directly evaluated by flow cytometry without washing steps.

For the analysis, total leukocytes were gated for their CD45 positivity and divided into granulocytes, peripheral blood mononuclear cells (PBMC), myeloid cells and lymphocytes based on their different granularity that is, using the 'side scatter' (SSC) physical parameter of the flow cytometer. Among the lymphocytes, the different immune populations were dissected based on the staining with the other antibodies (Abs) present in the kit, namely a combination of CD3, CD4 and CD8 for the different $\mathrm{T}$ cells subsets, CD19 for B cells and CD16 as well as CD56 for NK cells. Finally, the counting beads present in the 
Trucount tubes for calculation of the absolute cell counts were detected based on their granularity and high fluorescence in all channels, with the allophycocyanin (APC) channel allowing the best separation from the various immune populations (online supplemental figure 2).

In-depth phenotypical evaluation of immune cell subsets

For phenotypical evaluation, the Ab panels given in online supplemental table 1 were used. For detection of surface molecules (surf-1 to surf-7), $100 \mu \mathrm{L}$ of total blood were incubated for $15 \mathrm{~min}$ at RT with the different $\mathrm{Ab}$ followed by erythrocytes' lysis for $10 \mathrm{~min}$ in the BD FACS lysing solution and washing of the samples twice before measurement.

For the panels including intracellular antigens (intra- 8 to intra-12), the blood was first stained for the surface markers and then the cells were fixed and permeabilized using the transcription factor kit (BD Bioscience) or the Foxp3 transcription factor kit (Thermo Fisher) following the manufacturer's instructions. After this step, the samples were stained for $30 \mathrm{~min}$ at $4^{\circ} \mathrm{C}$ with Abs directed against the intracellular markers and washed twice prior to measurement.

For the analysis, single immune cells were first gated based on the combination of physical parameters (SSC as well as the 'area' and 'height' value of the forward scatter) and CD45 expression. The different immune cell subsets were obtained based on the staining for 'lineage' markers similarly to the gating strategy reported in online supplemental figure 2 and evaluated for the expression of functional/ activation markers. Data are reported as percentages of the indicated populations.

\section{Statistical analysis}

Comparison of flow cytometry data over time as well as between patients with or without pCR was performed using Student's t-test. ORs were calculated with GraphPad Prism with the Fisher's exact test or $\chi^{2}$ test after patients were dichotomized in 'high' and 'low' group based on the median value of each biomarker. For the variation over time, a normalized fold change in the biomarker between the time points (ie, (Biomarker ${ }_{\mathrm{B} \text { or }} \mathrm{C}^{- \text {Biomar- }^{-}}$ $\operatorname{ker}_{\mathrm{A}}$ )/ Biomarker $_{\mathrm{A}}$, abbreviated as ' $\mathrm{B}$ to $\mathrm{A}$ ' or ' $\mathrm{C}$ to $\mathrm{A}$ ', respectively) was used as value for statistical evaluation. The Spearman's correlation matrix from GraphPad Prism was used to evaluate correlations among different markers.

\section{RESULTS}

\section{Changes in absolute immune cell counts during treatment}

Total leukocyte counts progressively decreased in the cohort from recruitment (time point A), through the first phase of treatment with Nab-Pac (time point B) until surgery at the end of chemotherapy (time point $\mathrm{C}$; figure $1 \mathrm{~A})$, when a mean reduction of $15 \%$ in the leukocyte counts was found (figure 1B). Despite that, in almost one-fourth of the patients ( 15 out of 49 evaluable at all three time points) there was an opposite trend with increased cell counts at surgery (figure 1B). In the patients with reduced counts, four patients had leukopenia $(<3000$ cell $/ \mu \mathrm{L}$, dashed line in figure $1 \mathrm{~A}$ and $\mathrm{C})$ after Nab-Pac and eight patients at surgery (figure 1C).

Further dissection of leukocytes as described in online supplemental figure 2 revealed almost constant granulocyte counts (figure 1D) with a mean decrease at surgery of only $6.99 \%$ (figure 1B), but with 17 patients that in contrast had increased granulocyte counts at treatment ends compared with recruitment. By evaluation of granulocytopenia/neutropenia $(<2000 \mathrm{cell} / \mu \mathrm{L}$, dashed line in figure 1D,E), 7 and 12 patients had neutropenia after Nab-Pac or at surgery, respectively, with two patients being neutropenic at both time points with one in recovery, while the second patient was further loosing cells (figure 1E). Interestingly, only four patients were both leukopenic and neutropenic at surgery.

The determination of mononuclear cells revealed a loss of cell counts in the PBMC fraction that was paralleled by an even stronger decrease of lymphocytes $(32 \%$ and $49 \%$ reduction, respectively, figure $1 \mathrm{~B}$ and $\mathrm{F}$ ), which resulted in an almost doubled ratio between granulocytes and lymphocytes (data not shown). On the contrary, the myeloid cells were significantly increased at surgery (figure 1G). Dissection of the lymphocytes into the different subpopulations highlighted further differences in the sensitivity to treatment. Indeed, a significant drop of $>90 \%$ was found for CD19 $19^{+}$cells and a loss of nearly $50 \%$ of NK and $40 \%$ of T cells at time point $\mathrm{C}$ compared with $\mathrm{A}$ was detected (figure $1 \mathrm{~B}$ and $\mathrm{H}$ ). Interestingly, the different $\mathrm{T}$ lymphocyte subsets exhibited a distinct sensitivity to chemotherapy. $\mathrm{CD} 4^{+} \mathrm{T}$ cells were almost halved at surgery, whereas $\mathrm{CD} 8^{+} \mathrm{T}$ cell counts were more slightly reduced (figure 1B,I). Consequently, the ratio between $\mathrm{CD}^{+}$and $\mathrm{CD} 8^{+} \mathrm{T}$ cells was significantly reduced at time point $\mathrm{C}$ (figure $1 \mathrm{~J}$ ).

\section{In-depth analyses of immune cell subsets}

In the next step, a deeper characterization of the immune cell phenotypes was undertaken to evaluate possible differences in the sensitivity to standard neoadjuvant chemotherapy. Since in the TBNK kit for absolute cell count determination no marker for monocytes was present and the expansion of myeloid cells was only evaluated based on physical characteristics, monocytes were specifically stained and classified into classical, intermediate and inflammatory cells based on the expression levels of CD14 and $\mathrm{CD} 16\left(\mathrm{CD} 14^{\mathrm{high}}, \mathrm{CD} 14^{+} \mathrm{CD} 16^{+}\right.$and $\mathrm{CD} 16^{+} \mathrm{CD} 14^{\mathrm{dim}}$, respectively; gating strategy in online supplemental figure $3 \mathrm{~A})$. As shown in figure $2 \mathrm{~A}$, all monocyte subsets were enriched in the PBMC at the end of chemotherapy.

In line with the almost complete loss of $\mathrm{B}$ cell numbers, further functional dissection of CD19 CD20 doublepositive $\mathrm{B}$ cells based on the expression of membrane IgD molecule and CD27 (gating strategy in online supplemental figure 3B) highlighted a similar decrease of the four subsets at surgery, with preswitch and switch 

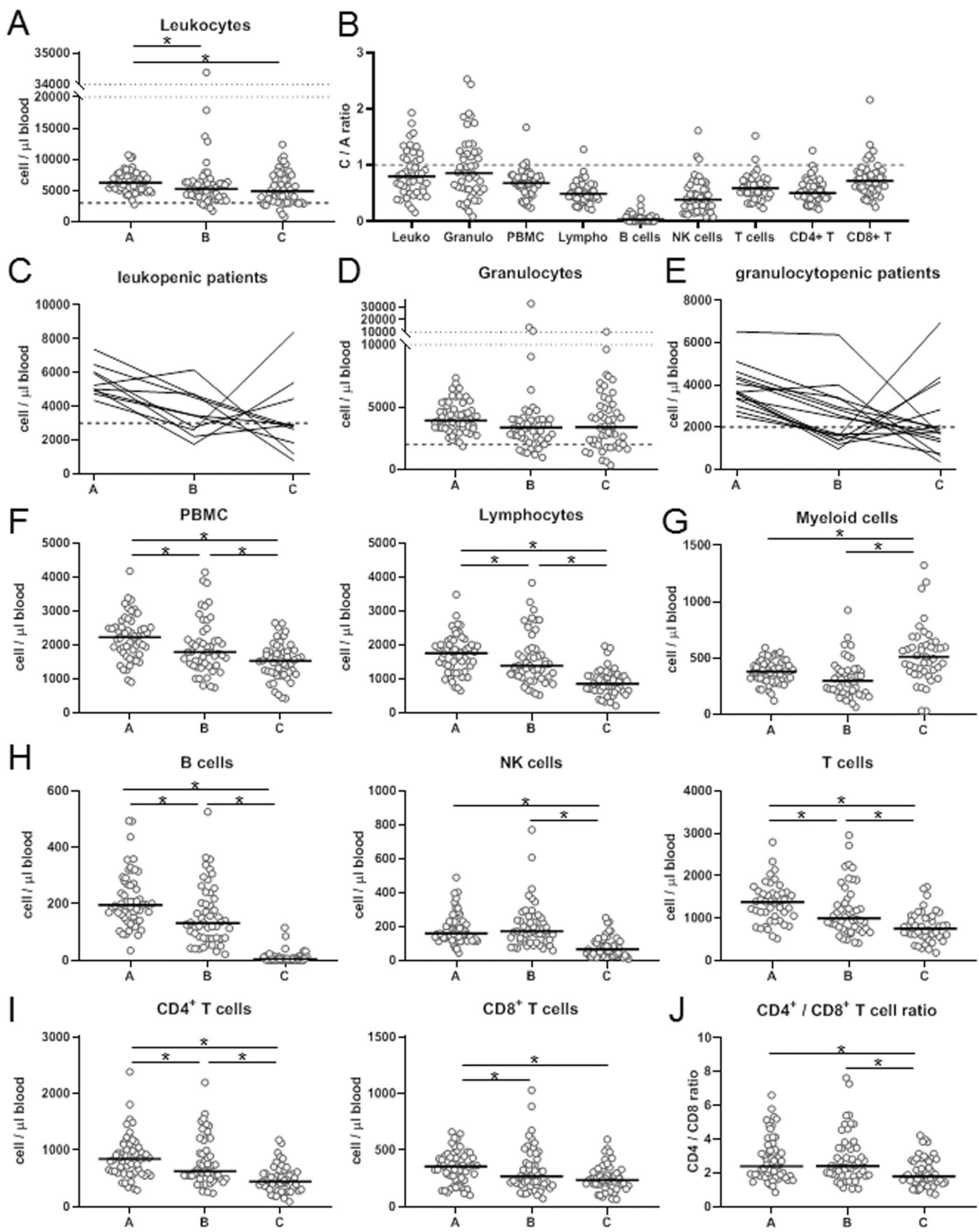

Figure 1 Substantial loss of $B$, natural killer $(\mathrm{NK})$ and $\mathrm{CD} 4^{+} \mathrm{T}$ cells during neoadjuvant therapy. Blood samples taken from up to 56 patients at three different time points ( $A=$ recruitment, $B=$ after nanoparticle albumin-bound paclitaxel (Nab-Pac), $C=a t$ surgery) were evaluated by flow cytometry and the absolute cell counts per microliter $(\mu \mathrm{L})$ blood calculated by mean of counting beads. In plots $\mathrm{A}$ and $\mathrm{C}$ to $\mathrm{I}$, the absolute cell counts of the different immune cell populations at the three time points are given for all the evaluated patients or for those having leukopenia or neutropenia at least at one time point (plot $\mathrm{C}$ and $\mathrm{E})$. In $\mathrm{B}$, the ratios between the cell counts at the last and the first time points are provided, whereas in $\mathrm{J}$ the ratio between $\mathrm{CD} 4^{+}$and $\mathrm{CD} 8^{+}$ T cells during treatment are calculated. Shown are the values of each individual donor together with their median (bold line). Dotted lines highlight $y$-axis brakes, dashed lines in panel $A$, and $C$ to $E$ represent the level for leukopenia/neutropenia. ${ }^{*} P<0.05$ paired Student's t-test. In C, one of the leukopenic patients at surgery had no blood draw after Nab-Pac and is therefore not depicted in the graph. In E, two of the neutropenic patients at surgery had no blood draw after Nab-Pac and are therefore not depicted in the graph. PMBC, peripheral blood mononuclear cells.

memory cells that were already dropping after the first phase of treatment (figure 2B). In contrast, there was a statistically significant increase in B cells that lost the CD20 marker (figure 2B).

Subclassification of NK cells (gating strategy in online supplemental figure 3C) revealed a significant decrease in the 'cytotoxic' $\mathrm{CD} 16^{+} \mathrm{CD} 56^{\mathrm{dim}}$ population at surgery, while the 'cytokine-producing' CD56 ${ }^{\text {br }}$ NK cells were more stable and also statistically significantly increased at the end of the treatment (figure 2C).

Despite the loss in absolute numbers, $\mathrm{T}$ cell frequencies expanded when evaluated as percentages of PBMC (figure 2D), and that applied to $\mathrm{CD} 8^{+}$, and to $\mathrm{CD} 4^{+} \mathrm{T}$ cells, whose absolute numbers were more strongly decreasing (figures 1 and 2D). Also less frequent $\mathrm{T}$ cell subsets, like those expressing the gamma/delta TCR ( $\gamma \delta$ T cells) 

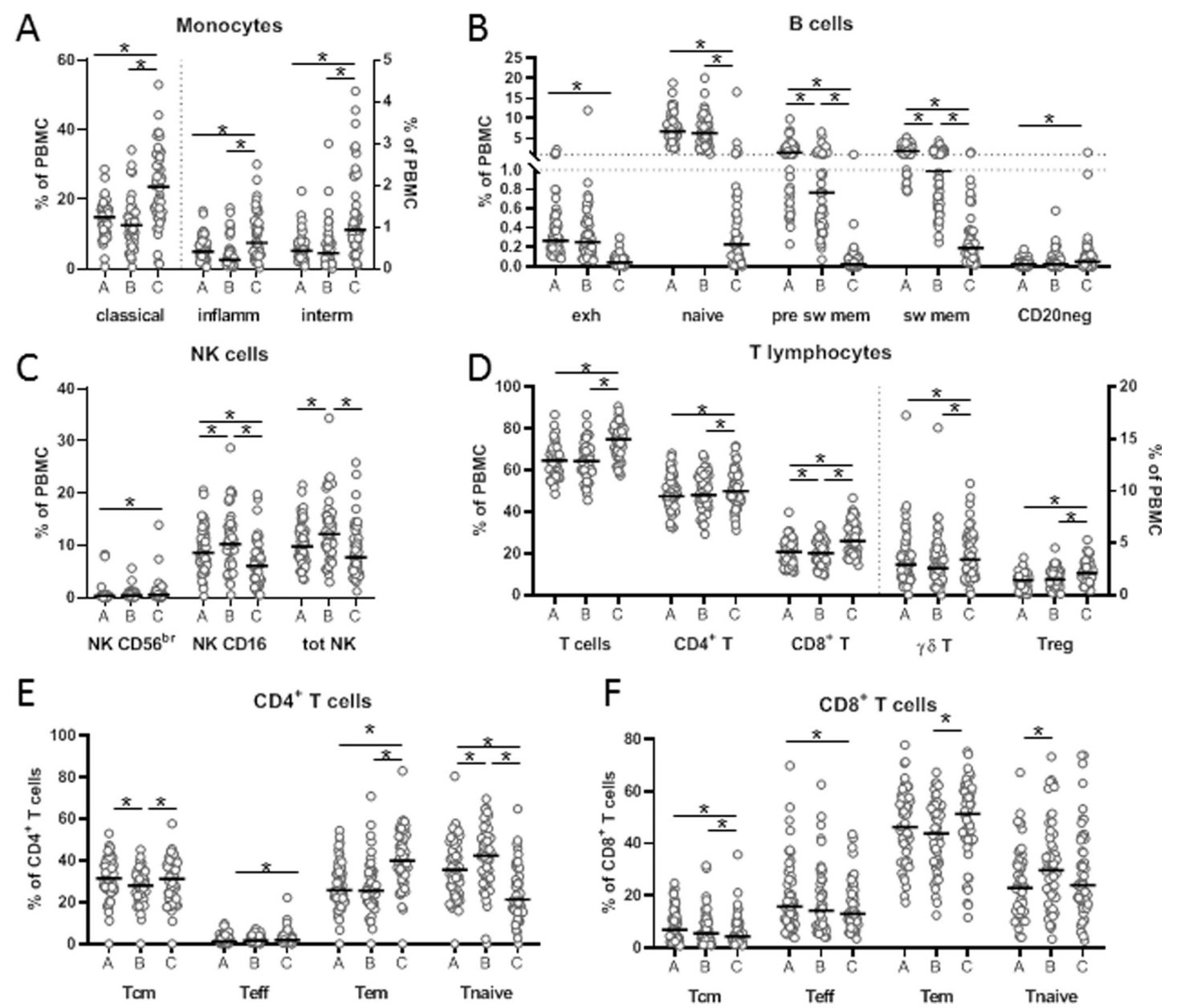

Figure 2 Changes in the major lymphocyte subsets during treatment. The major immune cell populations of the blood were characterized in depth for subsets and phenotypes. Shown are the percentages among total peripheral blood mononuclear cells (PBMC), $\mathrm{CD}^{+}$or $\mathrm{CD8}^{+} \mathrm{T}$ cells, as indicated, for each individual donor together with their median (bold line) at the different time points. The right-side $y$-axis is used in A for inflammatory and intermediate monocytes, whereas in $D$ for $\gamma \delta T$ cells and regulatory T cells (Tregs). Horizontal dotted lines highlight $y$-axis brakes, dotted vertical lines separation of samples reporting to the right-side $y$-axis. ${ }^{*} \mathrm{P}<0.05$ paired Student's t-test.

and $\mathrm{CD} 25^{+} \mathrm{Foxp}^{+} \mathrm{CD} 127^{\text {low }}$ regulatory $\mathrm{T}$ cells (Tregs), were expanded in percentages at the end of treatment (figure 2D and gating strategies in online supplemental figure 3D,E). Functional subdivision of $\mathrm{CD}^{+}$and $\mathrm{CD} 8^{+}$ $\mathrm{T}$ cells based on the staining with CD45RO and CCR7 (gating strategy in online supplemental figure 3F) highlighted a different sensitivity to the two phases of chemotherapy and also among the different subsets. Regarding $\mathrm{CD}^{+} \mathrm{T}$ cells, after the Nab-Pac treatment there was a reduction of the central memory $\left(\mathrm{T}_{\mathrm{cm}}\right)$ subset, whereas at surgery after also EC treatment the naive cells diminished, resulting in an overall expansion of effector $\left(\mathrm{T}_{\text {eff }}\right)$ and effector memory $\left(\mathrm{T}_{\text {eff }}\right)$ cells (figure $\left.2 \mathrm{E}\right)$. The changes among $\mathrm{CD} 8^{+} \mathrm{T}$ cells were more reduced, with the various subsets that responded to Nab-Pac similarly to the $\mathrm{CD}^{+} \mathrm{T}$ cells, whereas at surgery both $\mathrm{T}_{\mathrm{cm}}$ and $\mathrm{T}_{\text {eff' }}$, but not naïve cells decreased (figure 2F).

\section{Functional characterization of innate and adaptive immune cells}

Immune cells were also evaluated for possible functional alterations. During the treatment there was an increase in $\mathrm{CD}^{+} \mathrm{T}$ cells that express programmed cell death protein 1 (PD1), CD16 and CD57 as well as the chemokine receptor CCR6, whereas $\mathrm{CD} 38^{+}$cells were reduced (figure $3 \mathrm{~A}$ ). Among $\mathrm{CD}^{+} \mathrm{T}$ cells, there was an increased presence in $\mathrm{CD} 16^{+}$, and of $\mathrm{CD} 38^{+}$cells. Despite $\mathrm{PD} 1$ expression within $\mathrm{CD}^{+} \mathrm{T}$ cells was not significantly altered, there was an upregulation of the exhaustion marker Tim3 (figure 3B and data not shown). In parallel to a reduction in the NK cell numbers, there was also a statistically significant loss of their functional properties characterized by a slightly enhanced percentage of cells with loss of the CD3 $\zeta$ signaling chain and/or of the pore-forming molecule perforin (figure $3 \mathrm{C}$ and online supplemental figure 3G).

\section{Correlation of the changes in the frequency or phenotypes of immune cell subsets}

Comparison of the different immune cell populations and their variation during the two phases of therapy revealed that the expression of different functional markers strongly correlated among different immune populations (figure 4A). For example, expression of programmed 

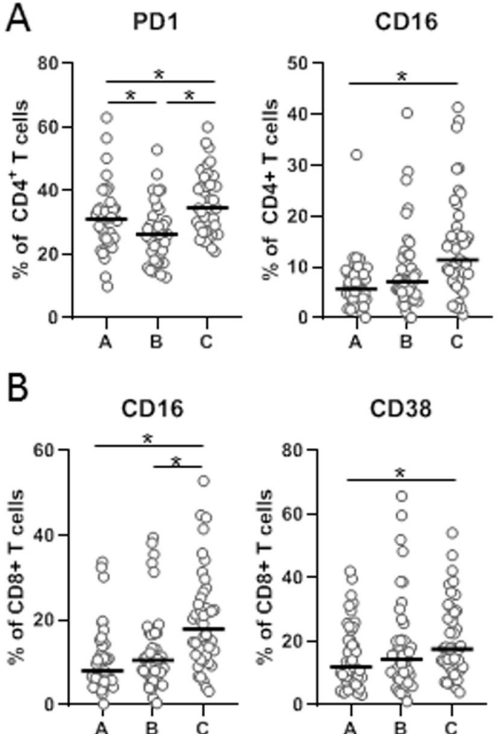
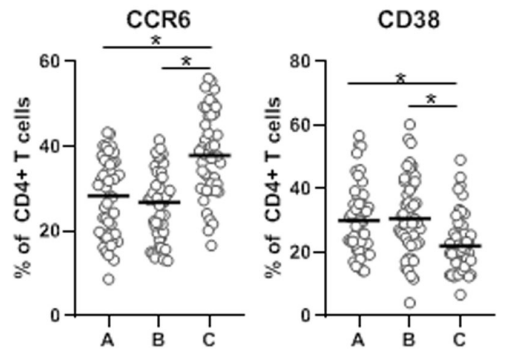

C
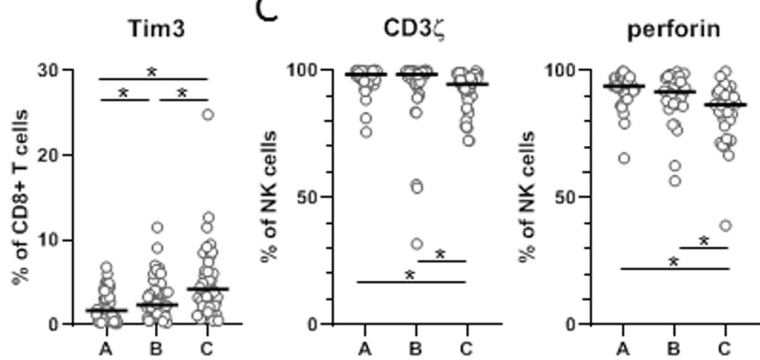

Figure 3 Phenotypical and functional changes in T and natural killer (NK) cells during treatment. Expression of the indicated functional molecules was evaluated within $\mathrm{CD}^{+}(\mathrm{A})$ and $\mathrm{CD}^{+} \mathrm{T}$ cells $(\mathrm{B})$ as well as NK cells $(\mathrm{C})$. Shown are the percentages of marker positive cells at different time points of each individual patient together with their median value (bold line). ${ }^{*}<<0.05$ paired Student's t-test.

death-ligand 1 (PD-L1) on $\mathrm{CD} 4^{+}$and $\mathrm{CD} 8^{+} \mathrm{T}$ cells strongly correlated from baseline throughout the two phases of chemotherapy whereas for PD1 the correlation was significant, but less strong. For the exhaustion marker Tim3, a significant, but not as strong correlation between $\mathrm{CD} 4^{+}$ and $\mathrm{CD}^{+} \mathrm{T}$ cells was present at recruitment but then lost on treatment (figure 4A). In addition, other molecules like CD16, CD28 or HLA-DR, particularly in combination with CCR7, showed a strong correlation within the two T cell subsets (figure 4A). Regarding the functional molecules $\mathrm{CD} 3 \zeta$ and perforin, a strong correlation in their expression was found among $\mathrm{CD} 4^{+}$and $\mathrm{CD} 8^{+} \mathrm{T}$ cells and with respect to NK cells, particularly in the early phases of chemotherapy (figure 4A).

Within the $\mathrm{CD}^{+} \mathrm{T}$ cells, changes in the expression of CD3 $\zeta$ and perforin at surgery showed a correlation with the expression of activation/exhaustion markers (online supplemental figure 4). The strongest was a negative correlation between $\mathrm{CD} 8^{+} \mathrm{T}$ cells expressing both functional molecules with those expressing neither PD1 nor its ligand PD-L1 (ie, CD $3 \zeta^{+}$perf $^{+}$vs PD1 ${ }^{\text {neg }}$ PD$\mathrm{L} 1^{\text {neg }}$ ) and for those that have lost both functional molecules and those expressing both exhaustion receptors PD1 and Tim3 (ie, CD3 $3^{\text {neg }}$ perf ${ }^{\text {neg }}$ vs $\mathrm{PD}^{+}{ }^{+} \mathrm{Tim}^{+}$; figure $4 \mathrm{~B}, \mathrm{C})$.

Correlations within different immune populations were mostly found after the first phase of chemotherapy, but due to the reduced number of evaluable patients the real significance might be biased by the presence of outlier patients. Such correlations are between NK cells losing the $\mathrm{CD} 3 \zeta$ chain $\left(\mathrm{CD} 3 \zeta^{\text {neg }}\right.$ perf $\left.^{+}\right)$and the intermediate monocytes (figure $4 \mathrm{D}$ ) and between $\mathrm{CD} 4^{+} \mathrm{T}$ cells expressing perforin either alone (data not shown) or together with the $\mathrm{CD} 3 \zeta$ chain and the preswitch as well as switch memory B cells (figure $4 \mathrm{E}, \mathrm{F}$ ).

\section{Immune markers at recruitment correlating with pCR}

Overall, 31 out of 56 analyzed patients $(54.4 \%)$ had a pCR after chemotherapy treatment. Comparison of biomarkers at recruitment between responder and non-responder patients highlighted that both the absolute numbers of NK cells in the blood as well as their frequency within the PBMC varied among the two clinical outcomes with higher levels in the responding patients (figure 5A, left and middle). In addition, the percentages of $\mathrm{CD}^{+} \mathrm{T}$ cells expressing neither CCR7 nor CD38 were significantly lower in the responders (figure 5A, right and online supplemental figure $3 \mathrm{H}$ ). To evaluate the ORs of pCR, patients were divided into biomarker high and low based on the median value of each biomarker. Again, a positive effect of high NK cell frequencies as total population and as the cytokineproducing $\mathrm{CD} 56^{\mathrm{br}}$ subset or the functionally active cells expressing both the CD3 $\zeta$ signaling chain and perforin was found (figure 4B). Furthermore, some T cell subpopulations, mostly within the $\mathrm{CD}^{+}$subsets, had a positive or negative association with the clinical outcome (figure 5B).

\section{Changes in immune markers during treatment correlating with PCR}

Changes in the frequency of various immune cell populations at surgery with respect to recruitment were then evaluated for a possible association with the clinical outcome. Responding patients had a statistically significant enhanced increase in both $\mathrm{CD} 4^{+}$and $\mathrm{CD} 8^{+} \mathrm{T}$ cells expressing the exhaustion marker PD1 (figure 6A and online supplemental figure 5). Other markers were significantly different between responders and non-responders with the former having lower levels of $\mathrm{CD}^{+} \mathrm{T}$ cells co-expressing CD38 and CCR7 or higher 


\begin{tabular}{|c|c|c|c|c|c|c|c|c|}
\hline \multicolumn{3}{|l|}{$A$} & \multicolumn{3}{|c|}{ Spearman $r_{3}$} & \multicolumn{3}{|c|}{ Sample size } \\
\hline marker & \multicolumn{2}{|c|}{ populations } & $\mathrm{A}$ & B to $A$ & $\mathrm{C}$ to $\mathrm{A}$ & $\mathrm{A}$ & $B$ to & $\mathrm{C}$ to $\mathrm{A}$ \\
\hline PD-L1 & $\mathrm{CD} 4 \mathrm{~T}$ & $\mathrm{CD} 8 \mathrm{~T}$ & 0.724 & 0.744 & 0.707 & 54 & 50 & 48 \\
\hline PD1 & $\mathrm{CD} 4 \mathrm{~T}$ & $\mathrm{CD} 8 \mathrm{~T}$ & 0.639 & 0.736 & 0.657 & 48 & 43 & 41 \\
\hline PD1 1neg PD-L1+ & $\mathrm{CD} 4 \mathrm{~T}$ & $\mathrm{CD} 8 \mathrm{~T}$ & 0.715 & 0.632 & 0.754 & 43 & 39 & 36 \\
\hline PD1 $1^{\text {neg }} P D-L 1^{\text {neg }}$ & $\mathrm{CD} 4 \mathrm{~T}$ & $\mathrm{CD} 8 \mathrm{~T}$ & 0.621 & 0.715 & 0.735 & 43 & 39 & 36 \\
\hline $\mathrm{PD}_{1}{ }^{\mathrm{PD}} \mathrm{\textrm {L }} 1^{+}{ }^{+}$ & $\mathrm{CD} 4 \mathrm{~T}$ & $\mathrm{CD} 8 \mathrm{~T}$ & 0.683 & 0.653 & 0.796 & 43 & 39 & 36 \\
\hline Tim3 & $\mathrm{CD} 4 \mathrm{~T}$ & $\mathrm{CD} 8 \mathrm{~T}$ & 0.505 & ns & ns & 54 & 50 & 49 \\
\hline CD16 & $\mathrm{CD} 4 \mathrm{~T}$ & CD8T & 0.526 & 0.782 & 0.679 & 53 & 48 & 49 \\
\hline $\mathrm{CD} 28$ & $\mathrm{CD} 4 \mathrm{~T}$ & $\mathrm{CD} 8 \mathrm{~T}$ & 0.642 & 0.760 & 0.472 & 53 & 48 & 49 \\
\hline HLA-DR & $\mathrm{CD} 4 \mathrm{~T}$ & CD8T & 0.622 & 0.543 & 0.796 & 54 & 50 & 50 \\
\hline HLA-DR ${ }^{+}$CCR7 $7^{+}$ & $\mathrm{CD} 4 \mathrm{~T}$ & $\mathrm{CD} 8 \mathrm{~T}$ & 0.729 & 0.731 & 0.724 & 53 & 49 & 49 \\
\hline 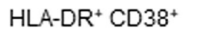 & $\mathrm{CD} 4 \mathrm{~T}$ & $\mathrm{CD} 8 \mathrm{~T}$ & 0.442 & 0.727 & 0.695 & 53 & 49 & 49 \\
\hline HLA-DR+ CD $45 R O$ & $\mathrm{CD} 4 \mathrm{~T}$ & $\mathrm{CD} 8 \mathrm{~T}$ & 0.638 & 0.588 & 0.771 & 53 & 49 & 49 \\
\hline $\operatorname{cD} 3 \zeta^{+}$ & $\mathrm{CD} 4 \mathrm{~T}$ & $\mathrm{CD} 8 \mathrm{~T}$ & 0.932 & 0.937 & 0.799 & 51 & 47 & 46 \\
\hline $\mathrm{CD} 3 \zeta^{\text {nes }}$ perf $f^{+}$ & $\mathrm{CD} 4 \mathrm{~T}$ & $\mathrm{CD} 8 \mathrm{~T}$ & 0.675 & 0.978 & 1.000 & 32 & 15 & 20 \\
\hline $\mathrm{CD} 3 \zeta^{+}$perforeg & $\mathrm{CD} 4 \mathrm{~T}$ & $\mathrm{CD} 8 \mathrm{~T}$ & 0.681 & 0.594 & 0.737 & 32 & 15 & 20 \\
\hline $\mathrm{CD} 3 \zeta^{\mathrm{reg}}$ perf fog & $\mathrm{CD} 4 \mathrm{~T}$ & $\mathrm{CD} 8 \mathrm{~T}$ & 0.940 & 0.854 & 0.761 & 32 & 15 & 20 \\
\hline $\mathrm{CD} 3 \zeta^{\text {nog }}$ perfros & $\mathrm{CD} 4 \mathrm{~T}$ & NK cell & 0.707 & 0.710 & 0.419 & 32 & 15 & 20 \\
\hline $\mathrm{CD} 3 \zeta^{\text {reg }}$ perfiog & $\mathrm{CD} 8 \mathrm{~T}$ & NK cell & 0.804 & 0.664 & 0.688 & 32 & 15 & 20 \\
\hline $\mathrm{CD} 3 \zeta^{\text {neg }}$ perf & $\mathrm{CD} 8 \mathrm{~T}$ & NK cell & 0.730 & 0.614 & ns & 32 & 15 & 20 \\
\hline
\end{tabular}

B

C

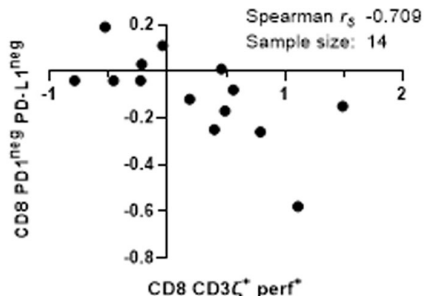

D

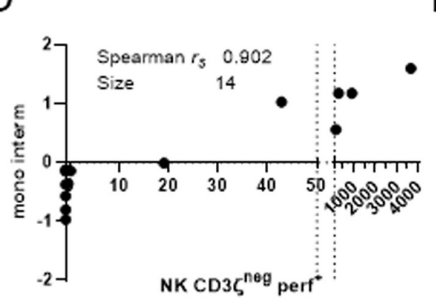

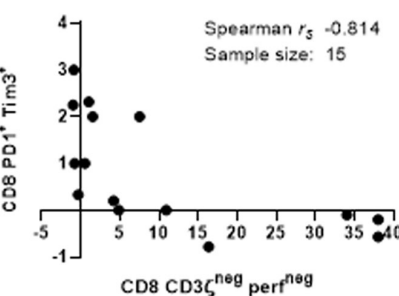

$E$

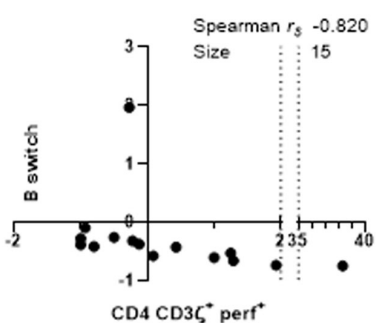

$\mathrm{F}$

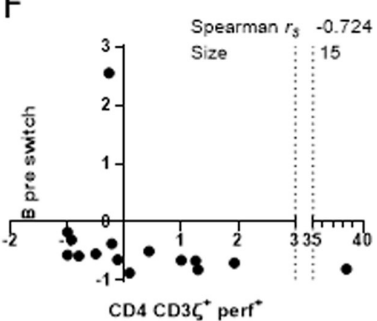

Figure 4 Correlation among the different immune populations during treatment. (A) The Spearman's correlation of the indicated functional markers among the given cell populations at the different phases of chemotherapy is provided together with the number of samples available for evaluation. ns, non-significant. (B-F) Correlation plots for the changes in the indicated markers or populations at surgery ( $B$ and $C$ ) or after nanoparticle albumin-bound paclitaxel (Nab-Pac) (D-F) are shown together with the value of the Spearman's coefficient and the number of samples available for the evaluation.

frequencies of Slan-expressing monocytes (SlanMo, figure $6 \mathrm{~A}$ and online supplemental figure $3 \mathrm{H}$ and $\mathrm{I}$ ). When the changes of markers were dichotomized into high and low and evaluated with respect of patients' pCR, none of them showed an association with the clinical outcome, whereas the loss of CD16 expression by $\mathrm{CD}^{+} \mathrm{T}$ cells correlated with pCR (figure $6 \mathrm{~B}$ ). While dichotomized PD1 expression was not associated with pCR, its expression on $\mathrm{CD}^{+} \mathrm{T}$ cells in the absence of its ligand PD-L1 paralleled with better outcome, even if the significance was reached only with the $\chi^{2}$ test and not the Fisher's exact test (figure 6B). In the case of $\mathrm{CD} 4^{+} \mathrm{T}$ cells, a decrease (or lower increase) of cells expressing neither the receptor nor its ligand significantly associated with pCR, again only in the $\chi^{2}$ test (figure $6 \mathrm{~B}$ and online supplemental figure $3 \mathrm{~J}$ ).

\section{Correlation of immune markers with known TNBC predicting marker}

In order to evaluate the possible independent predicting value of the immune populations identified in this exploratory study, their correlation with known prediction factors in TNBC was evaluated, namely with the percentage of $\mathrm{Ki} 67^{+}$tumor cells as well as the frequency of stromal TILs evaluated as described by Loibl $e t a l^{3}$ Despite its general role in TNBC, Ki67 was not associated with the clinical outcome in our cohort, whereas the stromal TILs significantly correlated with the pCR ( $\mathrm{p}=0.0014$ in t-test). Regarding the immune markers associated with $\mathrm{pCR}$, none of them had a significant correlation with stromal TILs (online supplemental table 2), whereas the frequency at baseline of $\mathrm{PD} 1{ }^{\text {neg }} \mathrm{PD}-\mathrm{L} 1{ }^{\text {neg }} \mathrm{CD} 4^{+} \mathrm{T}$ cells had a significant, but not 
A
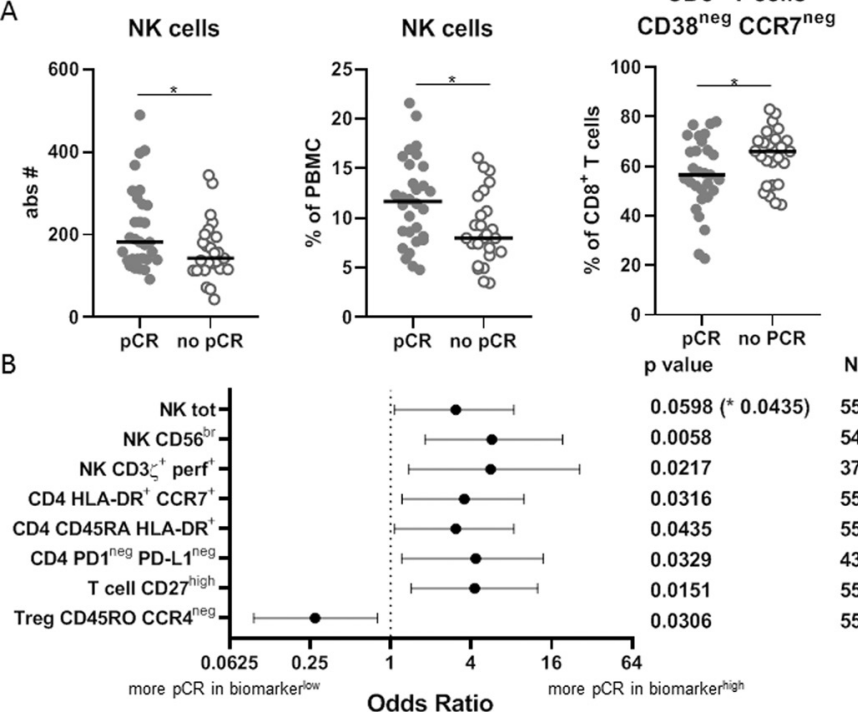

Figure 5 Marker at recruitment associated with pathological complete response ( $p C R)$. (A) For each individual patient the absolute number (left) or percentages within peripheral blood mononuclear cells (PBMC) (center) of natural killer (NK) cells as well as the percentage of $\mathrm{CD}^{+} \mathrm{T}$ cells expressing neither CCR7 nor CD37 (right) are shown on patients' subdivision into responder (pathological complete response $(p C R))$ and non-responder (no pCR). Bold lines represent the median value of each biomarker. ${ }^{*} \mathrm{P}<0.05$ paired Student's t-test. (B) For each biomarker, patients were subdivided into a 'high' and 'low' group relative to the biomarker median. Shown are the ORs $\pm \mathrm{Cl}$ for the clinical outcome for the markers statistically significant together with the $p$ values of the Fisher's exact test (or the $\chi^{2}$ test among brackets), and the number of patients $(\mathrm{N})$ that were evaluable for each parameter.

strong correlation with Ki67 (online supplemental table 2, Spearman's $r=0.319)$.

\section{DISCUSSION}

In this study, we performed a deep immune monitoring on blood samples from patients with early TNBC undergoing neoadjuvant chemotherapy in order to determine the effects of the different drugs on the various immune cell populations. These data will serve as rationale for combining this regimen with immunotherapeutic approaches, such as adoptive transfer, iCPI and/or vaccination. Despite the limited number of patients involved in this cohort and thus the reduced statistical power of the population, we evaluated possible immune markers of response to neoadjuvant chemotherapy that on validation in additional cohort(s) might help to stratify patients responding to such treatment versus those that would require combination strategies.

With respect to the two phases of the neoadjuvant treatment of the GeparNuevo trial, much higher impacts on the immune cell repertoire in the blood was recorded at the end of the treatment than after the first phase with weekly Nab-Pac. In line with other studies using Nab-Pac followed by EC, ${ }^{67}$ we found only few cases of leukocytopenia and/or neutropenia that were almost all of low grade. On the contrary, usage of EC before Nab-Pac resulted in $50 \%$ of treated patients with BC having neutropenia at the end of treatment, with $18 \%$ of them having grade 3 or higher neutropenia. ${ }^{8}$ These data suggest that the sequence Nab-Pac plus EC might be better for combination with immunotherapy than the opposite one. However, the stronger effects recorded at surgery might also be explained by long-term consequences of Nab-Pac and/or the sum of the two treatments and not only by an intrinsic stronger immune-depleting effect of EC.

At surgery, a more profound decrease in mononuclear cells than in total leukocytes was found, which resulted in an increased granulocyte-to-lymphocyte ratio. Despite its worse prognostic and predictive significance in other trials, ${ }^{9-11}$ such parameter did not show any association with the pCR of our cohort.

In-depth analysis of the PBMC demonstrated pronounced differences in the sensitivity of different immune cells to chemotherapy. For example, $\mathrm{CD} 4^{+}$and $\mathrm{CD}^{+} \mathrm{T}$ cells were differentially affected with a more significantly decrease in the absolute numbers of $\mathrm{CD} 4^{+}$ $\mathrm{T}$ cells when compared with $\mathrm{CD}^{+} \mathrm{T}$ cells, even despite the percentages within the PBMC were increasing in both cases. From a therapeutic view point, the 'resistance' of $\mathrm{CD}^{+} \mathrm{T}$ cells to both phases of the neoadjuvant
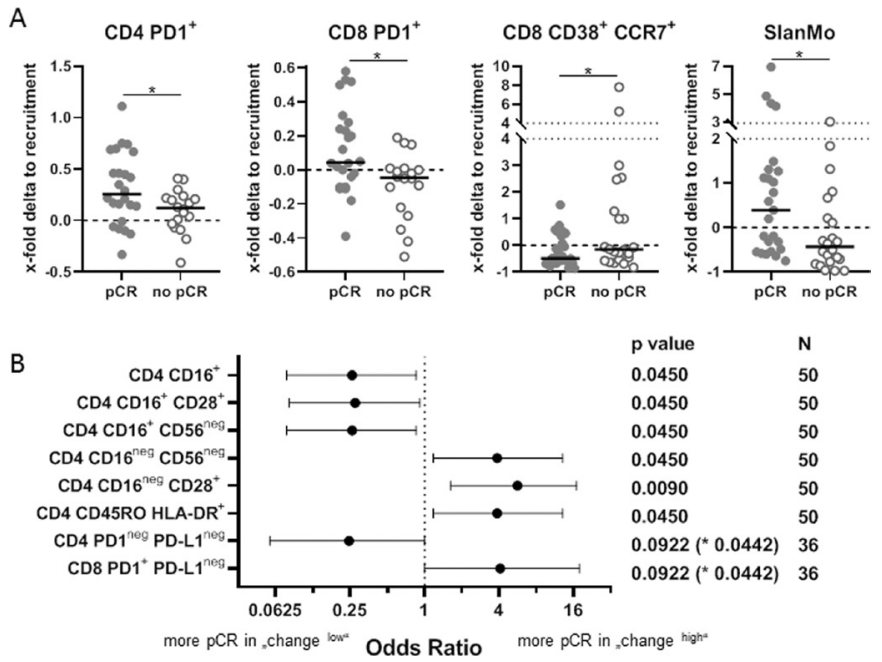

Figure 6 Changes in biomarker at surgery after epirubicin and cyclophosphamide (EC). For each immune population the $\mathrm{x}$-fold delta between time point $\mathrm{C}$ and $\mathrm{A}$ was calculated. (A) The individual values for markers statistically significantly different between responder (pathological complete response $(p C R))$ and non-responder (no $p C R$ ) patients are shown together with their median value (bold line). ${ }^{*} \mathrm{P}<0.05$ in Student's t-test. (B) Shown are the $\mathrm{OR} \pm \mathrm{Cl}$ for markers statistically significant associating with clinical outcome in the Fisher's exact test or in the $\chi^{2}$ test on subdivision of the patients on the base of changes higher or lower than the median change. The $p$ value for the Fisher's exact test, and among brackets those for the $\chi^{2}$ test are provided together with the number $(\mathrm{N})$ of patients for which the changes during treatment were evaluated. 
treatment could have important consequences, since it might be possible to combine adoptive transfer of in vitro expanded TILs or genetically modified cytotoxic T cells with such chemotherapeutic protocol. In contrast, vaccination strategies requiring the help of $\mathrm{CD} 4^{+} \mathrm{T}$ cells should be performed before chemotherapy, or at least already during the first phase of treatment with Nab-Pac when the $\mathrm{CD} 4^{+} \mathrm{T}$ cells are still in 'normal' numbers. There exist also reports, where the lympho-depleting activity of cyclophosphamide has been used in an adjuvant setting to 'make space' for the following transfer of in vitro activated PBMC, ${ }^{12}$ thus adding (adoptive) immunotherapy after the chemotherapy. A similar approach was used in the TONIC trial, where doxorubicin has been found to provide the best 'pretreatment' for patients' subsequent response to PD1 blockade. ${ }^{13}$

In addition to changes in their numbers and frequencies, chemotherapy induced also some changes in the functional phenotype of lymphocytes. Regarding $\mathrm{CD}^{+} \mathrm{T}$ cells, only few changes in the distribution of the memory subsets were found, but an enhanced expression of the markers CD38 and Tim3 was detected. These data suggest an ongoing immune activation followed by an upregulation of negative feedback pathways. Despite no significant increase in the percentage of $\mathrm{CD}^{+} \mathrm{T}$ cells expressing the 'prototypical' activation/exhaustion marker PD1 was detected along treatment, an increased PD1 expression was observed in responders versus non-responders at surgery and enhanced levels of $\mathrm{CD} 8^{+} \mathrm{T}$ cells expressing PD1 in the absence of its ligand PD-L1 appear to have a positive effect on pCR (figure 6B). Thus, Nab-Pac plus EC induces an immune activation of $\mathrm{CD}^{+} \mathrm{T}$ cells that associate with clinical response suggesting that the addition of iCPI targeting the PD1/PD-L1 axis might further improve the therapeutic activity of neoadjuvant chemotherapy. In light of the correlations found at surgery between variation in the expression of functional molecules and combination of exhaustion markers involving PD1, a deeper evaluation of the real co-expression of such molecules and their role in the patients' clinical outcome is required in additional validation cohort(s).

The $\mathrm{CD}^{+} \mathrm{T}$ cell population underwent more pronounced changes than $\mathrm{CD}^{+}$lymphocytes, such as a loss of naive cells at surgery that could either be due to death or to differentiation into effector or effector memory cells. Phenotypically, there was an increased expression of CCR6 that could represent a shift toward Th17 cells, but also of PD1 and CD57 indicating an ongoing activation associated with an upregulation of exhaustion markers. As for $\mathrm{CD}^{+} \mathrm{T}$ cells, changes in PD1 expression of $\mathrm{CD}^{+} \mathrm{T}$ cells at surgery were different in responder and non-responder patients, but significance was only reached for cells expressing neither the receptor nor the ligand, with higher pCR relating to loss of these 'neither activated nor exhausted' cells. In contrast, high pretreatment levels of such double-negative $\mathrm{CD}^{+} \mathrm{T}$ cells had a positive effect on the clinical outcome suggesting that starting high levels of those cells indicate the absence of a pre-existing exhaustion, while their loss on neoadjuvant chemotherapy represent an induced immune cell activation that might play a direct role in patients' outcome. Another potential predictive marker for $\mathrm{CD} 4^{+}$ $\mathrm{T}$ cells was the upregulation of CD16, which has been demonstrated to be induced on $\mathrm{CD}^{+} \mathrm{T}$ cells on in vitro activation and to be also endowed of signaling function. ${ }^{14}$ Thus, expression of $\mathrm{CD} 16$ on $\mathrm{CD} 4^{+} \mathrm{T}$ cells might be a further possible sign of immune activation during chemotherapy that will require further validation as well as functional characterization.

The frequency of Tregs also increased during chemotherapy, not significantly after Nab-Pac, but significantly at surgery, when evaluated as percentages of total PBMC or within $\mathrm{CD}^{+} \mathrm{T}$ cells (data not shown). This outcome is in contrast to in vitro and in vivo results of apoptosis induction ${ }^{1516}$ and reduced frequencies of Tregs in the blood in response to paclitaxel or cyclophosphamide. ${ }^{1718}$ This discrepancy might be due to the different doses used for treatment or the cancer type analyzed, but might also relate to the discovery that (allogeneic) stimulated Tregs can detoxify cyclophosphamide by upregulating aldehyde dehydrogenase (ALDH) ${ }^{19}$ Moreover, cyclophosphamide when given at low metronomic doses has only a transient effect on the number of Tregs. ${ }^{20}$ In contrast, epirubicin has been reported to have an inhibitory effect on Foxp3 function in both reporter assays and in murine models, thus reducing the activity of Tregs without affecting their numbers. ${ }^{21}$ Despite the lack of significant differences between responder and non-responder patients, low levels of memory Tregs at baseline associated with pCR.

Another population that displayed bivalent response to chemotherapy were NK cells. Indeed, a decreased number of the total population of $\mathrm{CD} 3{ }^{\text {neg }} \mathrm{CD} 56^{+}$cells was detected, but further dissection into the cytotoxic $\mathrm{CD} 16^{+} \mathrm{CD} 56^{\mathrm{dim}}$ subset and the more cytokine producer $\mathrm{CD} 56^{\mathrm{br}}$ subset highlighted a decrease of the former and an increase of the latter. Thus, an almost opposite effect to $\mathrm{T}$ lymphocytes is found with the killer subset that is lost, while the cytokine-producing subpopulation is unaffected or slightly increased. Interestingly, the number of NK cells prior to treatment had a positive association with the patients' outcome. Dichotomization of the markers revealed a significant effect of higher percentages of total NK cells as well as of the CD $56^{\text {br }}$ subset and of the cytotoxic subset expressing the lytic molecule perforin and the signaling chain of the $\mathrm{CD} 3 \zeta$ receptor. This positive effect is in line with other studies, where the expression of NK cell genes in BC samples in vitro correlate with the sensitivity to paclitaxel treatment ${ }^{22}$ and enhanced levels of NK cells expressing the activation marker CD69 correlate with better prognosis for patients with BC. ${ }^{23}$

Another unexpected result was the almost complete loss of all B cell subsets in response to EC with the exception of a slight increase in B cells loosing CD20 expression, which might represent terminally differentiated plasma cells on their way to the bone marrow or lymphoid tissue. Therefore, it would be interesting to evaluate if the 
loss of B cells in the cohort analyzed is due to death or a shifted differentiation to terminally differentiated plasma cells with an altered trafficking/enhanced retention in secondary lymphoid organs or in tertiary lymphoid structures within/near the tumor. Therapeutically, most immunotherapy approaches do not target B cells despite their prognostic value for TNBC. ${ }^{24}{ }^{25}$ Indeed, in metastatic patients the presence of B cells in sentinel lymph nodes, independent of the tumor infiltration status, prognosticate a longer disease-free survival. ${ }^{24}$ Similarly, CD38 ${ }^{+}$blast $\mathrm{B}$ cells in the tumor infiltrate have a prognostic value. ${ }^{25}$ Despite these data, the role of the humoral response in the direct antitumor activity is highly debated. In light of the higher infection rates of patients undergoing chemotherapy, ${ }^{26}$ the prognostic value of $\mathrm{B}$ cells could also be due to a 'tumor independent' effect and depend mostly on the protection from opportunistic infections.

Finally, monocytes were also increased along treatment, with all the evaluated subsets having similar changes. Neither markers specific for myeloid derived suppressor cells nor the absolute HLA-DR levels on the monocytes were evaluated. Consequently, no conclusions on the functional capability of the myeloid compartment or on the possible expansion of functionally impaired or actively suppressing myeloid cells in response to chemotherapy could be drawn. Since no differences were found between responding and non-responding patients, the expanded myeloid cells seem to play neither positive nor negative role on the patients' outcome in our cohort. The only antigen-presenting cells significantly differing between responders and non-responders were the 6-sulfo LacNac expressing monocytes (SlanMo), for which both protumor and antitumor effects have been described. ${ }^{27-29}$ In this study, responding patients had an increased frequency in SlanMo at surgery suggesting a possible antitumor activity in TNBC, but on dichotomization of the cohort the association with pCR was not significant. Further analysis of their functional properties including the pattern of secreted cytokines or expression of costimulatory molecules is required to further dissect the population and possibly obtain a subpopulation of SlanMo with predictive capability for patients with TBNC.

In sum, EC treatment or the long-term effect and synergy of the two chemotherapy phases had a profound impact on different immune cell subsets, whereas Nab-Pac had more restricted effects suggesting that active immunotherapy approaches should be performed prior to chemotherapy or during the first weeks of treatment. An upregulation of different immune checkpoint molecules like PD1 and Tim3 indicate an activation of the immune system that could further profit from combinations with iCPI strategies. Despite the limited size of the analyzed cohort and the exploratory nature of this study, different parameters at recruitment or their changes along treatment were found to associate with response to neoadjuvant chemotherapy and none of them was correlating with the frequency of stromal TILs suggesting that they might represent new independent predicting factors.
Thus, the results obtained are hypothesis generating and will require further evaluation in additional, larger validation cohorts to confirm their potential role in discriminating patients that would benefit from such treatment from those that would need a combination with another therapy.

\section{CONCLUSION}

The neoadjuvant treatment of patients with TNBC based on Nab-Pac followed by EC results in an altered composition of the immune cell repertoire, but should still allow combination with different immunotherapeutic strategies to further improve the patients' outcome.

\section{Author affiliations}

${ }^{1}$ Insitute of Medical Immunology, Martin Luther University Halle Wittenberg, Halle, Sachsen-Anhalt, Germany

${ }^{2}$ Department of Obstetrics and Gynecology, Goethe University Frankfurt, Frankfurt am Main, Hessen, Germany

${ }^{3}$ Institute of Pathology, Philipps-Universitat Marburg, Marburg, Hessen, Germany ${ }^{4}$ Nationales Centrum für Tumorerkrankungen, Deutsches Krebsforschungszentrum, Heidelberg, Baden-Württemberg, Germany

${ }^{5}$ Rotkreuzklinikum Munchen, Munchen, Bayern, Germany

${ }^{6}$ Brustzentrum, Charite Universitatsmedizin Berlin, Berlin, Germany

${ }^{7}$ SRH Wald-Klinikum Gera, Gera, Thüringen, Germany

${ }^{8}$ Department of Obstetrics and Gynecology, Sana Klinikum Offenbach GmbH, Offenbach, Hessen, Germany

${ }^{9}$ Department of Obstetrics and Gynecology, Universitätsklinikum SchleswigHolstein, Kiel, Schleswig-Holstein, Germany

${ }^{10}$ Praxis für Hämatologie und Onkologie Koblenz, Koblenz, Germany

${ }^{11}$ Universitätsfrauenklinik, Universität Heidelberg, Heidelberg, Baden-Württemberg, Germany

${ }^{12}$ Universitätsklinikum Ulm, Ulm, Baden-Württemberg, Germany

${ }^{13}$ Department of Obstetrics and Gynecology, Universitätsklinikum HamburgEppendorf, Hamburg, Hamburg, Germany

${ }^{14}$ Mammazentrum, Krankenhaus Jerusalem, Hamburg, Germany

${ }^{15}$ Department of Obstetrics and Gynecology, Uniklinik RWTH Aachen, Aachen, Nordrhein-Westfalen, Germany

${ }^{16}$ Department of Gynecology and Obstetrics, Universitätsklinikum Erlangen, Erlangen, Bayern, Germany

${ }^{17}$ Department of Obstetrics and Gynecology, HELIOS Klinikum Berlin-Buch, Berlin, Germany

${ }^{18}$ Department of Medicine and Research, German Breast Group, Neu-Isenburg, Hessen, Germany

Acknowledgements The authors would like to thank Nicole 0tt for excellent secretarial help and Dr Valentina Vladimirova, GBG for editing the manuscript. This work was sponsored by a grant from Celgene.

Contributors $\mathrm{CM}$ performed data analysis, $\mathrm{AM}$ and $\mathrm{KB}$ performed data acquisition; $\mathrm{CM}$ and $\mathrm{BS}$ discussed the results and wrote the paper draft. TK, CD, KW and SL contributed to paper draft; AS, CH, J-UB, D-MZ, CJ, JT, JH and MU provided patients' samples and clinical data; all coauthors reviewed the paper.

Funding The GeparNuevo trial was financially supported by AstraZeneca and Celgene. This translational research study was financially supported by the GBG Forschungs GmbH, Celgene, the German Cancer Aid (grant \#70113450, CD, BS, SL) and the Mildred-Scheel Stiftung (grant \# 70113311, BS).

Competing interests TK has a patent pending; AS has grants from Celgene, Roche, AbbVie Molecular Partner, personal fees from Roche, AstraZeneca, Celgene, Pfizer, Novartis, MSD, Tesaro and Lilly; CH has personal fees from Roche, Novartis, Celgene, Pfizer, Lilly and AstraZeneca; CJ has personal fees from Roche, Celgene and Amgen; $\mathrm{JH}$ has grants and personal fees from Novartis and Celgene, grants from Hexal, personal fees and other from Pfizer and Roche, personal fees from Lilly, MSD, AstraZeneca and AbbVie, and other from Daichi; VM has grants and personal fees from Roche, personal fees from Amgen, AstraZeneca, ClinSol, Daiichi-Sankyo, Eisai, Genomic Health, Hexal, Pfizer, Roche, Pierre Fabre, MSD, Novartis, Tesaro, 
Teva, Seattle Genetics, Lilly and Nektar, consultancy honoraria from Genomic Health, Hexal, Roche, Pierre Fabre, Amgen, ClinSol, Novartis, MSD, Daiichi-Sankyo, Eisai, Lilly, Tesaro, Nektar, and other from Novartis, Roche, Seattle Genetics, Genentech; ES has personal fees from Roche, Pfizer, AstraZeneca and Tesaro; MU has personal fees from PUMA Biotechnology and Pierre Fabre and personal fees and non-financial support from Lilly, MSD, Mundipharma, Myriad Genetics, Odonate, Pfizer, Roche, Sanofi Aventis, Teva, Novartis and Clovis Oncology; SL has grants and other from AstraZeneca, Celgene, AbbVie, Amgen, Novartis, Pfizer and Roche, other from Seattle Genetics and PriME/Medscape, personal fees from Chugai, grants from Teva and Vifor, grants and other from Daiichi-Sankyo, other from Lilly, Samsung, Eirgenix, BMS, Puma and MSD, grants from Immunomedics, and a pending patent; BS has a grant from Cellgene.

\section{Patient consent for publication Not required.}

Ethics approval The clinical study was approved by the ethics committee and the competent authority. All patients provided written informed consent for study conduct, biomaterial collection and analysis.

Provenance and peer review Not commissioned; externally peer reviewed.

Data availability statement Data are available on reasonable request. The datasets used and/or analyzed during the current study are available from the corresponding author on reasonable request.

Supplemental material This content has been supplied by the author(s). It has not been vetted by BMJ Publishing Group Limited (BMJ) and may not have been peer-reviewed. Any opinions or recommendations discussed are solely those of the author(s) and are not endorsed by BMJ. BMJ disclaims all liability and responsibility arising from any reliance placed on the content. Where the content includes any translated material, BMJ does not warrant the accuracy and reliability of the translations (including but not limited to local regulations, clinical guidelines, terminology, drug names and drug dosages), and is not responsible for any error and/or omissions arising from translation and adaptation or otherwise.

Open access This is an open access article distributed in accordance with the Creative Commons Attribution Non Commercial (CC BY-NC 4.0) license, which permits others to distribute, remix, adapt, build upon this work non-commercially, and license their derivative works on different terms, provided the original work is properly cited, appropriate credit is given, any changes made indicated, and the use is non-commercial. See http://creativecommons.org/licenses/by-nc/4.0/.

\section{ORCID iDs}

Thomas Karn http://orcid.org/0000-0002-3264-6573

Barbara Seliger http://orcid.org/0000-0002-5544-4958

\section{REFERENCES}

1 Murphy BL, Day CN, Hoskin TL, et al. Neoadjuvant chemotherapy use in breast cancer is greatest in excellent responders: triplenegative and HER2+ subtypes. Ann Surg Oncol 2018;25:2241-8.

2 Denkert C, von Minckwitz G, Darb-Esfahani S, et al. TumourInfiltrating lymphocytes and prognosis in different subtypes of breast cancer: a pooled analysis of 3771 patients treated with neoadjuvant therapy. Lancet Oncol 2018;19:40-50.

3 Loibl S, Untch M, Burchardi N, et al. A randomised phase II study investigating durvalumab in addition to an anthracycline taxanebased neoadjuvant therapy in early triple-negative breast cancer: clinical results and biomarker analysis of GeparNuevo study. Ann Oncol 2019;30:1279-88.

4 Schmid P, Adams S, Rugo HS, et al. Atezolizumab and nabpaclitaxel in advanced triple-negative breast cancer. N Engl J Med 2018;379:2108-21.

5 Shurin MR, Naiditch H, Gutkin DW, et al. ChemolmmunoModulation: immune regulation by the antineoplastic chemotherapeutic agents. Curr Med Chem 2012;19:1792-803.

6 Hahn A, Schlotter CM, Rossmanith WG, et al. Neoadjuvant chemotherapy for breast cancer with weekly nab-paclitaxel followed by epirubicin and cyclophosphamide--results of a case series. In Vivo 2014;28:235-41.

7 Shimada H, Ueda S, Saeki T, et al. Neoadjuvant triweekly nanoparticle albumin-bound paclitaxel followed by epirubicin and cyclophosphamide for stage II/III HER2-negative breast cancer: evaluation of efficacy and safety. Jpn J Clin Oncol 2015;45:642-9.
8 Murphy C, Muscat A, Ashley D, et al. Tailored neoadjuvant epirubicin, cyclophosphamide and nanoparticle albumin-bound paclitaxel for breast cancer: the phase II NEONAB trial-Clinical outcomes and molecular determinants of response. PLoS One 2019;14:e0210891.

9 Chae S, Kang KM, Kim HJ, et al. Neutrophil-Lymphocyte ratio predicts response to chemotherapy in triple-negative breast cancer. Curr Oncol 2018;25:113-9.

10 Patel DA, Xi J, Luo J, et al. Neutrophil-To-Lymphocyte ratio as a predictor of survival in patients with triple-negative breast cancer. Breast Cancer Res Treat 2019;174:443-52.

11 Qiu X, Song Y, Cui Y, et al. Increased neutrophil-lymphocyte ratio independently predicts poor survival in non-metastatic triple-negative breast cancer patients. IUBMB Life 2018;70:529-35.

12 Rüttinger $\mathrm{D}$, van den Engel NK, Winter $\mathrm{H}$, et al. Adjuvant therapeutic vaccination in patients with non-small cell lung cancer made lymphopenic and reconstituted with autologous PBMC: first clinical experience and evidence of an immune response. $J$ Trans/ Med 2007;5:43.

13 Voorwerk L, Slagter M, Horlings HM, et al. Immune induction strategies in metastatic triple-negative breast cancer to enhance the sensitivity to PD-1 blockade: the tonic trial. Nat Med 2019;25:920-8.

14 Chauhan AK, Chen C, Moore TL, et al. Induced expression of

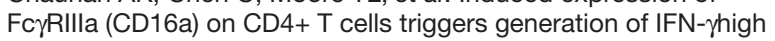
subset. J Biol Chem 2015;290:5127-40.

15 Liu N, Zheng Y, Zhu Y, et al. Selective impairment of CD4+CD25+FoxP3+ regulatory T cells by paclitaxel is explained by $\mathrm{Bcl}-2 / \mathrm{Bax}$ mediated apoptosis. Int Immunopharmacol 2011;11:212-9.

16 Dimeloe S, Frick C, Fischer M, et al. Human regulatory $T$ cells lack the cyclophosphamide-extruding transporter ABCB1 and are more susceptible to cyclophosphamide-induced apoptosis. Eur J Immunol 2014;44:3614-20.

17 Zhang L, Dermawan K, Jin M, et al. Differential impairment of regulatory $\mathrm{T}$ cells rather than effector $\mathrm{T}$ cells by paclitaxel-based chemotherapy. Clin Immunol 2008;129:219-29.

18 Huijts CM, Werter IM, Lougheed SM, et al. Phase 1 study of everolimus and low-dose oral cyclophosphamide in patients with metastatic renal cell carcinoma. Cancer Immunol Immunother 2019;68:319-29.

19 Kanakry CG, Ganguly S, Zahurak M, et al. Aldehyde dehydrogenase expression drives human regulatory T cell resistance to posttransplantation cyclophosphamide. Sci Trans/ Med 2013;5:211ra157.

$20 \mathrm{Ge} \mathrm{Y,} \mathrm{Domschke} \mathrm{C,} \mathrm{Stoiber} \mathrm{N,} \mathrm{et} \mathrm{al.} \mathrm{Metronomic} \mathrm{cyclophosphamide}$ treatment in metastasized breast cancer patients: immunological effects and clinical outcome. Cancer Immunol Immunother 2012;61:353-62.

21 Kashima H, Momose F, Umehara H, et al. Epirubicin, identified using a novel luciferase reporter assay for FOXP3 inhibitors, inhibits regulatory T cell activity. PLoS One 2016;11:e0156643.

22 Garcia-Chagollan M, Carranza-Torres IE, Carranza-Rosales P, et al. Expression of NK cell surface receptors in breast cancer tissue as predictors of resistance to antineoplastic treatment. Technol Cancer Res Treat 2018;17:153303381876449.

23 Mandó P, Rizzo M, Roberti MP, et al. High neutrophil to lymphocyte ratio and decreased $\mathrm{CD} 69^{+} \mathrm{NK}$ cells represent a phenotype of high risk in early-stage breast cancer patients. Onco Targets Ther 2018;11:2901-10.

24 Blenman KRM, He T-F, Frankel PH, et al. Sentinel lymph node B cells can predict disease-free survival in breast cancer patients. NPJ Breast Cancer 2018;4:28.

25 Yeong J, Lim JCT, Lee B, et al. High densities of tumor-associated plasma cells predict improved prognosis in triple negative breast cancer. Front Immunol 2018;9:1209.

26 Waks AG, Tolaney SM, Galar A, et al. Pneumocystis jiroveci pneumonia $(\mathrm{PCP})$ in patients receiving neoadjuvant and adjuvant anthracycline-based chemotherapy for breast cancer: incidence and risk factors. Breast Cancer Res Treat 2015;154:359-67.

27 Toma M, Wehner R, Kloß A, et al. Accumulation of tolerogenic human 6-sulfo lacNAc dendritic cells in renal cell carcinoma is associated with poor prognosis. Oncoimmunology 2015;4:e1008342.

28 Vermi W, Micheletti A, Lonardi S, et al. slanDCs selectively accumulate in carcinoma-draining lymph nodes and Marginate metastatic cells. Nat Commun 2014;5:3029.

29 Vermi W, Micheletti A, Finotti G, et al. slan ${ }^{+}$Monocytes and Macrophages Mediate CD20-Dependent B-cell Lymphoma Elimination via ADCC and ADCP. Cancer Res 2018;78:canres.2344.2017-59. 